\title{
Antioxidant, antimicrobial, and GC-MS profiling of Saussurea obvallata (Brahma Kamal) from Uttarakhand Himalaya
}

\author{
Prabhakar Semwal ${ }^{*}$ and Sakshi Painuli
}

\begin{abstract}
Background: Saussurea obvallata (DC.) Edgew. (S. obvallata) is an endangered medicinal herb of the high altitude Himalayan region with immense cultural significance. This study is one of the first report of pharmacological evaluation and GC-MS analysis of methanolic extracts of leaves and flowers of S. obvallata.

Methods: Total flavonoid content (TFC) and total phenolic content (TPC) were performed according to standard protocols. The antioxidant activities of both the extracts (methanol and aqueous) were examined using two complementary methods, namely diphenylpicrylhydrazyl (DPPH) and Hydrogen peroxide $\left(\mathrm{H}_{2} \mathrm{O}_{2}\right)$ assay. While, antimicrobial potential examined by using classical assays on pathogenic microbial strains along with appropriate controls of antimicrobial agents. Gas Chromatographic-Mass Spectrometric analyses of methanolic extracts of $S$. obvallata were performed for the identification of bioactive components. Statistical analysis was performed by using SPSS version 16.0.

Results: The extracts of leaves and flowers of S. obvallata showed significant results for all pharmacological experiments. TPC was recorded from a range of $132.67 \pm 0.17$ to $358.67 \pm 0.17 \mathrm{mg} \mathrm{GAE} \mathrm{gm}^{-1} \mathrm{dw}$ while TFC was recorded from a range of $65.73 \pm 1.55$ to $326.88 \pm 2.11 \mathrm{mg} \mathrm{QE} \mathrm{gm}^{-1} \mathrm{dw}$. Per cent DPPH free radical scavenging activity was recorded from a range of $29.25 \pm 0.86$ to $82.88 \pm 0.48 \%$ whereas per cent $\mathrm{H}_{2} \mathrm{O}_{2}$ free radical scavenging activity were recorded from a range of $39.75 \pm 0.36$ to $41.05 \pm 0.46 \%$. Antimicrobial activity was analyzed against four bacterial strains and three fungal strains. S. obvallata extracts showed fine zone of inhibition against Pseudomonas aeruginosa, Klebsiella pneumoniae and Staphylococcus aureus, but Escherichia coli showed resistant (in terms of lower zone) against the extract compared to three bacteria. In antifungal activity, extract showed maximum zone of inhibition against Candida glabrata followed by Candida albicans and Candida tropicalis. GC-MS analysis of methanolic extracts of leaves and flowers of S. obvallata showed the presence of 36 and 48 components, respectively, based on retention time (Rt), and area per cent.

Conclusion: These findings confirm the traditional claims and contribute in providing promising baseline information for the pharmacological use of S. obvallata. Additional highly developed research is essential for isolation and identification of specific active components which are responsible for pharmacological properties of the plant.
\end{abstract}

Keywords: Antioxidant, Antimicrobial, Microbial strains, Pharmacological evaluation, Saussurea obvallata, Traditional claims

\footnotetext{
* Correspondence: semwal.prabhakar@gmail.com

Department of Biotechnology, Graphic Era (Deemed to be University), 566/6,

Bell Road, Clement Town, Dehradun, Uttarakhand 248 002, India
} 


\section{Background}

Herbal drugs are used in the traditional Indian system of medicine and also in other systems of medicine in the world for times immemorial due to low cost, effectiveness and no or low side effects. These attributes of the so called "natural" medicines are attracting the attention of increasingly large number of people of the world. World Health Organization (WHO) survey reports that $80 \%$ of the population in developing countries are still dependent on the traditional and folk systems of medicine, $85 \%$ traditional medicines are prepared by the use of plant extracts and that nearly $70 \%$ of prescribed human medicines are derived from the plants [1-3]. International market of herbal drugs is around US \$ 62 billion, which is poised to grow to US $\$ 5$ trillion by 2050 in the Asian and International market [4]. Demand of herbal drugs in India alone is estimated at US \$ 1 billion per year [5], and Uttarakhand is one of the richest source for a whole variety of medicinal plants.

Saussurea is a very important genus of the family Asteraceae due to a variety of reasons, and most species of this genus are well investigated at the international level [6-9]. However, little is known about S. obvallata $(2 n=32)$. It is an endemic herb of the Himalayan region and distributed between 3000 and $4800 \mathrm{~m}$ amsl. Commonly it is known as Brahma Kamal and is the state flower of Uttarakhand (India). It is a well known plant across Uttarakhand due to traditional, medicinal, ornamental and religious purposes [10]. It is used for the treatment of various diseases or disorders like paralysis, cerebral ischemia, wounds, cardiac disorders and mental disorders; some people also use it as antiseptic, in healing cuts, etc. [10]. Preliminary investigations about the phytochemicals found in S. obvallata (qualitative) have been reported by Semwal et al. [11], and its mineral composition has been described by Mishra et al. [12] The present study, deals with the estimation of its total phenolic and flavonoid contents, as well as antioxidant and antimicrobial activities associated with its extracts. Gas Chromatography-Mass Spectrometry (GC-MS) based analyses of crude methanolic extracts of S. obvallata leaves and flowers have been carried out for the identification of active components.

\section{Methods}

\section{Collection of plant material}

The plant material (leaves and flowers) was collected from Kedarnath valley (4335 $\mathrm{m}$ amsl, 3040'73" N latitude and $79^{\circ} 06^{\prime} 20^{\prime \prime}$ E longitude) in Uttarakhand, India, during the month of September, 2012. The identity was subsequently confirmed by Dr. Anup Chandra (Scientist-E) Systemic Botany, Forest Research Institute, Dehradun, Uttarakhand, India (Ref. n. GEU/DBT/AT-1PS/2013). The fresh material was kept in perforated poly bags and immediately brought to the laboratory.

\section{Preparation of extracts}

The extracts were prepared as per Sati and Joshi [13] with slight modification. The flower and leaf samples of S. obvallata were washed, dried, and powdered using an electric blender (Willey Grinder Mill, Micro Scientific, India). Two solvents, methanol or water, were used for the extraction of phyto-constituents from the dried powder.

\section{Methanol}

Methanolic extracts of leaves and flowers were prepared by the Soxhlet extraction procedure. In this method the powdered plant material $(1.0 \mathrm{~g})$ of leaves and flowers were extracted in $10 \mathrm{~mL}$ of $70.0 \%(\mathrm{v} / \mathrm{v})$ methanol used and extraction was carried out for $5 \mathrm{~h}$. Afterwards the extract was collected and filtered through two layers of muslin cloth and then the filtrate was transferred to a rotator vacuum evaporator (Strike-12, Steroglass, Italy) flask and dried under reduced pressure and temperature less than $\left(50{ }^{\circ} \mathrm{C}\right)$. Then dried extract was stored at $\left(-20^{\circ}\right.$ C) until used. The percentage yield of the plant extract was calculated according to the formula.

[Percent Yield of the extract $\left.(\%)=\mathrm{C}_{\mathrm{X}} / \mathrm{C}_{\mathrm{Y}} \times 100\right]$

Where, $C_{X}=$ Plant material weight after extraction process, $C_{Y}=$ Plant material weight taken for extraction.

\section{Water}

Aqueous extracts of leaves and flowers were prepared using maceration technique. In this method the powdered plant material $(1.0 \mathrm{~g})$ of leaves and flowers were extracted in $10 \mathrm{~mL}$ of $100 \%(\mathrm{v} / \mathrm{v})$ distilled water and allowed it to stand for $48 \mathrm{~h}$ (Shaker, $25 \pm 1{ }^{\circ} \mathrm{C}$ ). Afterwards the extract was filtered through two layers of muslin cloth and transferred to a rotator vacuum evaporator (Strike-12, Steroglass, Italy) flask and dried under reduced pressure and below $50{ }^{\circ} \mathrm{C}$. The dried extract was stored at $-20^{\circ} \mathrm{C}$ until used. The per cent yield of the extract was calculated using the formula giving in methanolic extraction.

\section{Determination of total phenolics}

The total phenolic content (TPC) in methanolic and aqueous extracts was determined by the Folin-Ciocalteu's reagent colorimetric method described by Anand et al. [14]. Both the methanolic and aqueous extracts of S. obvallata $(20 \mu \mathrm{L})$ were taken from the stock solutions $\left(1 \mathrm{mg} \mathrm{mL}^{-1}\right)$ of methanol and aqueous solutions, diluted with distilled water $(80 \mu \mathrm{L})$; this was then mixed with Folin-Ciocalteu 
reagent $(500 \mu \mathrm{L})$ and allowed to react for $5 \mathrm{~min}$ in the dark $\left(25 \pm 1{ }^{\circ} \mathrm{C}\right)$. The mixture was neutralized by adding $400 \mu \mathrm{L}$ of $7.5 \%$ sodium carbonate and kept in the dark $\left(25 \pm 1{ }^{\circ} \mathrm{C}\right.$, $30 \mathrm{~min}$ ). The absorbance of this blue colored mixture was measured at $765 \mathrm{~nm}$ using a spectrophotometer (Thermo Scientific UV- 10). Quantification was done on the basis of a standard curve prepared using gallic acid (Sigma Aldrich, G7384-100G) at the concentration of 0.2, 0.4, 0.6, 0.8 , and $1.0 \mathrm{mg} \mathrm{mL}^{-1}$ in $70.0 \%$ methanol. Based on the absorbance values, the TPC was estimated $\left(\mathrm{mg} \mathrm{mL}^{-1}\right)$ from the calibration curve and the results expressed in terms of $\mathrm{mg}$ gallic acid equivalent dry weight (GAE $\mathrm{g}^{-1}$ $\mathrm{dw})$. The whole process of TPC estimation was done and experiment was performed in triplicate.

\section{Determination of total flavonoids}

The total flavonoid content (TFC) was determined using the aluminium chloride colorimetric method, as described by Anand et al. [14]. Briefly, the methanolic or aqueous extracts of $S$. obvallata $(100 \mu \mathrm{L})$ from the respective stocks $\left(1 \mathrm{mg} \mathrm{mL}^{-1}\right)$ of methanol or aqueous solutions were first diluted with distilled water $(400 \mu \mathrm{L})$ and then $30 \mu \mathrm{L}$ of $5.0 \%$ aq. $\mathrm{NaNO}_{2}$ (sodium nitrite) solution was added to them. After $5 \mathrm{~min}, 30 \mu \mathrm{l}$ of $10.0 \%$ aq. $\mathrm{AlCl}_{3}$ (aluminium chloride) was added, and the mixture was allowed to stand for $5 \mathrm{~min}\left(25 \pm 1{ }^{\circ} \mathrm{C}\right)$. Subsequently $20 \mu \mathrm{L}$ of $4.0 \%$ aq. $\mathrm{NaOH}$ (sodium hydroxide) solution was added and the volume was made up to $1.0 \mathrm{~mL}$ with distilled water $(420 \mu \mathrm{L})$. The absorbance of this mixture was immediately measured using a UV spectrophotometer (Thermo Scientific UV- 10) at $510 \mathrm{~nm}$. Quantification was carried out on the basis of a standard curve prepared with quercetin (Sigma Aldrich, 337,951-25G) at the concentrations of $0.2,0.4,0.6,0.8$, and $1.0 \mathrm{mg}$ $\mathrm{mL}^{-1}$ in $70.0 \%$ methanol. The results were expressed in terms of mg quercetin equivalent dry weight (QE g $\mathrm{g}^{-1}$ $\mathrm{dw}$ ). The whole process of TFC estimation was carried out in triplicate.

\section{Determination of antioxidant activity by 1, 1-Diphenyl-2- picrylhydrazyl (DPPH) method}

The free radical scavenging activity of samples was assessed according to the method of Azzahra et al. [15]. Briefly, first the stock solution of DPPH (Merck-Millipore, 300,267-50MG) was prepared by dissolving $24 \mathrm{mg}$ DPPH in $100 \mathrm{~mL}$ methanol and the solution was stored at $-20{ }^{\circ} \mathrm{C}$ until used. Subsequently, the working solution was prepared by mixing $10 \mathrm{~mL}$ of stock with $60 \mathrm{~mL}$ of methanol, which gave an absorbance of $1.10 \pm 0.02$ units at $515 \mathrm{~nm}$. Both the extracts $(10 \mu \mathrm{L})$ were mixed with DPPH $(990 \mu \mathrm{L})$ and the reaction was allowed to proceed for $2 \mathrm{~h}\left(25 \pm 1{ }^{\circ} \mathrm{C}\right)$ in the dark, and then the absorbance was recorded at $515 \mathrm{~nm}$. Ascorbic acid (Sigma Aldrich, A92902-25G) was used as a standard for making the calibration curve using $0.2,0.4,0.6,0.8$, and $1.0 \mathrm{mg} \mathrm{mL}^{-}$

${ }^{1}$ concentrations of the standard. The estimations were carried out in triplicate, and the per cent scavenging activity was calculated using the formula:

$$
[\text { Scavenging rate }(\%)=[(\text { Ac-Ae }) / A c] \times 100]
$$

Where, Ac and Ae represent the absorbance values of the control and extract, respectively.

\section{Determination of antioxidant activity by hydrogen peroxide $\left(\mathrm{H}_{2} \mathrm{O}_{2}\right)$ method}

Determination of antioxidant activity by this method was carried out according to Panovska et al. [16]. Several oxidases generate $\mathrm{H}_{2} \mathrm{O}_{2}$, which is scavenged, either directly or indirectly via its reduction product, hydroxyl radical. In this method, when a scavenger is incubated with hydrogen peroxide, the decomposition or loss of $\mathrm{H}_{2} \mathrm{O}_{2}$ is measured using UV Spectrophotometer. Extracts $(1 \mathrm{~mL})$ were mixed with $20 \mathrm{mM} \mathrm{H}_{2} \mathrm{O}_{2}$ solution $(2 \mathrm{~mL})$ in phosphate buffer saline (PBS solution $\mathrm{pH} 7.5)$. The absorbance was measured after $10 \mathrm{~min}$ at $230 \mathrm{~nm}$ against phosphate buffer. $\mathrm{H}_{2} \mathrm{O}_{2}$ solution $(2 \mathrm{~mL})$ and the solvent $(1 \mathrm{~mL})$ were used as control and PBS as blank. Ascorbic acid (Sigma Aldrich, A92902-25G) was used as standard and the calibration curve was prepared using $0.2,0.4,0.6,0.8$, and $1.0 \mathrm{mg} \mathrm{mL}^{-1}$ concentrations of the standard. The per cent scavenging rate was calculated using the formula given for DPPH method.

\section{Determination of antibacterial activity}

The antimicrobial activity of S. obvallata extracts was carried out using standard protocols. Bacterial and fungal strains were obtained from the Microbial Type Culture Collection (MTCC), Institute of Microbial Technology (IMTECH), Chandigarh, India. Selection of bacterial and fungal strains was made on the basis of their pathogenic nature, wider availability, antibiotic resistance and popularity. The bacterial strains included three Gram-negative strains namely, Pseudomonas aeruginosa (MTCC 4306), Escherichia coli (MTCC 1698), and Klebsiella pneumoniae (MTCC 9544) and one Gram-positive strain namely, Staphylococcus aureus (MTCC 6908). The antibacterial activity of the extracts was estimated using the well diffusion method [17, 18]. Briefly, the extracts (methanolic or aqueous) were tested on Luria Bertani agar (LB agar; Himedia, Delhi, India) plates to detect antibacterial activity, if any, against $P$. aeruginosa, E. coli, K. pneumoniae and $S$. aureus. Bacterial strains were cultured in LB broth at $37^{\circ} \mathrm{C}$ for $18 \mathrm{~h}$. The cultures were diluted to $1 \times 10^{6}$ cells $\mathrm{mL}^{-1}$ in $\mathrm{LB}$ broth and $100 \mu \mathrm{L}$ of each was spreaded onto a separate LB agar plate. Wells of $6 \mathrm{~mm}$ diameter were bored using sterile cork borer. The extract $(20 \mu \mathrm{L})$ from individual stocks $\left(5 \mathrm{mg} \mathrm{mL}^{-1}\right.$ concentration), and 
ampicillin $(20 \mu \mathrm{L})$ from stock $\left(1 \mathrm{mg} \mathrm{mL}^{-1}\right.$ concentration) were poured in the wells and the plates were further incubated at $37^{\circ} \mathrm{C}$ for $24 \mathrm{~h}$. Ampicillin was used as a positive control, whereas DMSO (5\%) was used as a negative control. These tests were repeated three times to estimate consistency. Inhibition was measured in terms of zone of inhibition (ZOI) in $\mathrm{mm}$ formed on the plates.

\section{Determination of antifungal activity}

The well diffusion method was also used to screen the antifungal activity of $S$. obvallata extracts against three fungal strains of Candida namely, C. albicans (MTCC 3017), C. glabrata (MTCC 3019) and C. tropicalis (MTCC 3416) according to the same protocol $[17,18]$ giving in the previous section (antibacterial activity). These strains were also procured from the Institute of Microbial Technology (IMTECH), Chandigarh, India. Potato dextrose agar (PDA; Himedia, Delhi, India) was used as the culture medium. Fluconazole $\left(1 \mathrm{mg} \mathrm{mL}^{-1}\right)$ was used as a control drug (positive) and 5\% DMSO was used as a negative control. The extract $(20 \mu \mathrm{L})$ from individual stocks $\left(5 \mathrm{mg} \mathrm{mL}^{-1}\right)$ was placed in each well, and the inoculated plates were incubated at $28^{\circ} \mathrm{C}$ for 15 $\mathrm{h}$. These tests were done in triplicate and the average of three separate measurements was taken for the colony diameter $(\mathrm{mm})$ of the fungus.

\section{Gas chromatography-mass spectrometry (GC-MS) analyses}

GC-MS analyses and component identification of methanolic extracts of flowers and leaves of Saussurea obvallata were performed at the University Science Instrumentation Centre, Jawaharlal Nehru University, Delhi, India. The analyses were performed according to Ezhilan and Neelamegam [19], and Das et al. [20]. The GC-MS system (Shimadzu QP2010PLUS, Kyoto, Japan) was used for the analyses, which was equipped with an auto injector (AOC-20i), head space sampler (AOC-20s), and a fused silica capillary column Rtx-5 (30 m in length $\times 0.25 \mathrm{~mm}$ internal diameter $\times 0.25 \mu \mathrm{m}$ film thickness). The oven temperature was set at $100^{\circ} \mathrm{C}$ for $2 \mathrm{~min}$, then increased to $250{ }^{\circ} \mathrm{C}$ at a rate of $5^{\circ} \mathrm{C}$ per min, and finally to $280{ }^{\circ} \mathrm{C}$ at a rate of $10^{\circ} \mathrm{C}$ per min. One $\mu \mathrm{L}$ of each sample ( $1 \mathrm{mg} \mathrm{mL}^{-1}$ stock) was injected to the column in split mode (split ratio 10 ) with helium (99.99\% purity) as a carrier gas with a flow rate of $1.21 \mathrm{~mL}$ per min. The presence of unique peak fragmentation patterns for various metabolites/ phytocomponents was detected by an MS detector in full scan mode. Identification of components was based on their retention time (RT) and mass measured under identical GC-MS conditions. Quantitative determinations in the different samples were carried out using the peak areas. Identification of phytocomponents of Saussurea obvallata extracts was confirmed by comparing the spectral data of peaks with the standard mass spectra from the library data base [National Institute of Standards and Technology library (NIST08) and WILEY8]. Total running time of GC-MS was $50.74 \mathrm{~min}$ and the relative percentage of individual constituents was expressed on the basis of peak area normalization.

\section{Statistical analysis}

The results of phytochemical analyses and antimicrobial activity data were subjected to analysis of variance using SPSS version 16.0. The significance level was determined at $p<0.05$ and the means were separated using Duncan's multiple range test (DMRT), to determine if the values were significantly different. Data have been presented as mean values \pm standard error $(\mathrm{SE})$.

\section{Results and discussions}

\section{Total phenolic and flavonoid content}

Significant variation $(\mathrm{p}<0.05)$ was recorded in the total content of phenolics (TPC) and flavonoids (TFC) in $S$. obvallata, and the values for TPC and TFC were expressed in terms of $\mathrm{mg}$ gallic acid equivalent $\mathrm{g}^{-1} \mathrm{dw}$ (the standard curve equation: $\mathrm{y}=1.992 \mathrm{x} \quad 0.226, \mathrm{R}^{2}=$ 0.977) and quercetin equivalent $\mathrm{g}^{-1} \mathrm{dw}$ (the standard curve equation: $y=0.284 x+0.116, R^{2}=0.975$ ), respectively. The maximum and minimum TPC values were found in methanolic leaf extract and aqueous flower extract of $S$. obvallata $(358.66 \pm 0.17$ and $132.67 \pm 0.17$ mg GAE $\mathrm{g}^{-1} \mathrm{dw}$ ), respectively. Intermediate values were recorded for aqueous leaf extract $(139.50 \pm 0.28)$ and methanolic flower extract $(185.00 \pm 0.00)$. The maximum and minimum TFC values were recorded in aqueous flower extract and methanolic flower extract of S. obvallata $\left(326.88 \pm 2.12\right.$ and $65.73 \pm 1.55 \mathrm{mg} \mathrm{QE} \mathrm{g}^{-1}$ $\mathrm{dw})$, respectively. Intermediate values were recorded for aqueous leaf extract $(229.46 \pm 1.54)$ and methanolic leaves extract $(188.38 \pm 1.01)$. The results of TPC and TFC estimations have been represented in Table 1. These types of poly phenolic compounds are known to show different types of biological effects, e.g., antioxidant and antimicrobial activities, etc. [21].

\section{DPPH and $\mathrm{H}_{2} \mathrm{O}_{2}$ free radical scavenging activity}

Antioxidant activity was measured by two in-vitro assays and significant variation $(p<0.05)$ was recorded in antioxidant activity of $S$. obvallata extracts using DPPH assay, while significant variation $(\mathrm{p}<0.05)$ was not recorded in $\mathrm{H}_{2} \mathrm{O}_{2}$ assay. The maximum and minimum per cent DPPH free radical scavenging activity were recorded in the methanolic and aqueous extracts of flowers $(82.88 \pm 0.48 \%$ and $29.25 \pm 0.86 \%)$, respectively. Intermediate values of DPPH free radical scavenging activity were recorded for aqueous extract of leaves (49.66 
Table 1 Quantitative estimation of total phenolic, total flavonoid and free radical scavenging activity by DPPH and $\mathrm{H}_{2} \mathrm{O}_{2}$ assays in aqueous and methanolic extracts of leaves and flowers of Saussurea obvallata

\begin{tabular}{|c|c|c|c|c|c|}
\hline Plant extract & Yield of the extracts (\%) & TPC (mg GAE g $\left.{ }^{-1} d w \pm S E\right)$ & TFC (mg QE g $\left.{ }^{-1} d w \pm S E\right)$ & DPPH (\% S. activity \pm SE) & $\mathrm{H}_{2} \mathrm{O}_{2}$ (\% S. activity $\pm \mathrm{SE}$ ) \\
\hline$\overline{\mathrm{L} 1}$ & 13.70 & $139.50 \pm 0.29^{c}$ & $229.46 \pm 1.55^{b}$ & $49.67 \pm 0.38^{c}$ & $39.75 \pm 0.36$ \\
\hline L2 & 19.80 & $358.67 \pm 0.17^{\mathrm{a}}$ & $188.38 \pm 1.02^{c}$ & $73.48 \pm 0.44^{b}$ & $41.05 \pm 0.46$ \\
\hline F1 & 13.14 & $132.67 \pm 0.17^{d}$ & $326.88 \pm 2.11^{\mathrm{a}}$ & $29.25 \pm 0.86^{d}$ & $40.12 \pm 0.40$ \\
\hline F2 & 11.67 & $185.00 \pm 0.00^{b}$ & $65.73 \pm 1.55^{d}$ & $82.88 \pm 0.48^{\mathrm{a}}$ & $40.76 \pm 0.27$ \\
\hline
\end{tabular}

Values are expressed in mean \pm standard error; Mean values followed by the same letter (s) in a column are not significantly different ( $p<0.05)$ based on DMRT; TPC total phenolic content, TFC total flavonoid content, DPPH 1, 1-Diphenyl-2-picrylhydrazyl, $\mathrm{H}_{2} \mathrm{O}_{2}$ hydrogen peroxide, $L 1 \& L 2$ aqueous and methanolic extract of leaves, F1 \& F2 aqueous and methanolic extract of flowers, respectively

$\pm 0.38 \%)$ and methanolic extract of leaves (73.48 \pm $0.44 \%)$. On the other hand, the maximum and minimum per cent $\mathrm{H}_{2} \mathrm{O}_{2}$ free radical scavenging activity were recorded in methanolic leaf extract and aqueous leaf extract $(41.05 \pm 0.76 \%$ and $39.75 \pm 0.36 \%)$, respectively. Intermediate values of $\mathrm{H}_{2} \mathrm{O}_{2}$ free radical scavenging activity were recorded for aqueous extract of flowers and methanolic extract of flowers $(40.11 \pm 1.10 \%$ and $40.76 \pm 0.26 \%)$.

\section{Antibacterial activity}

Antibacterial activity of the extracts of leaves and flowers of Saussurea obvallata was measured in terms of zone of inhibition (ZOI) against Pseudomonas aeruginosa (PA), Escherichia coli (EC), Staphylococcus aureus (SA), and Klebsiella pneumoniae (KP). The maximum zone of inhibition (ZOI) for the aqueous extract of leaves was $20.43 \pm 0.30 \mathrm{~mm}$ for SA and minimum ZOI was $11.57 \pm$ $0.23 \mathrm{~mm}$ for EC. Intermediate ZOI $(16.60 \pm 0.21$, and $14.90 \pm 0.21 \mathrm{~mm}$ ) values were recorded for PA and KP, respectively. The maximum $\mathrm{ZOI}$ for methanolic extract of leaves was $19.90 \pm 0.56 \mathrm{~mm}$ for $\mathrm{KP}$ and minimum ZOI was $10.83 \pm 0.43 \mathrm{~mm}$ for $\mathrm{EC}$, while intermediate values for ZOI $(13.90 \pm 0.21 \mathrm{~mm}$ and $13.60 \pm 0.21 \mathrm{~mm})$ were recorded for PA and SA, respectively. The maximum ZOI for the aqueous extract of the flowers was $20.50 \pm 0.26$ $\mathrm{mm}$ for PA and minimum value for ZOI was $13.90 \pm$ $0.21 \mathrm{~mm}$ for $\mathrm{EC}$, while intermediate values for ZOI of $16.53 \pm 0.24 \mathrm{~mm}$ and $18.53 \pm 0.24 \mathrm{~mm}$ were recorded for
SA and KP, respectively. The maximum ZOI for methanolic extract of flowers of $S$. obvallata was found to be $16.33 \pm 0.17 \mathrm{~mm}$ for PA and minimum ZOI value of $8.86 \pm 0.18 \mathrm{~mm}$ was observed for $\mathrm{EC}$, while $12.83 \pm 0.16$ $\mathrm{mm}$ and $11.53 \pm 0.24 \mathrm{~mm}$ values for $\mathrm{ZOI}$ were recorded for SA and KP, respectively. Ampicillin (positive control) showed maximum ZOI against PA $(34.33 \pm 0.33 \mathrm{~mm})$ followed by SA $(31.33 \pm 0.33 \mathrm{~mm}), \mathrm{EC}(25.66 \pm 0.33 \mathrm{~mm})$, and KP $(24.6 \pm 0.30 \mathrm{~mm})$. Five per cent DMSO (negative control) did not show any ZOI for individual bacterial strains. In conclusion, it was observed that the extract of S. obvallata caused lower values for ZOI against EC in comparison to other bacteria (SA, PA \& KP). The results of antibacterial activity of extracts of $S$. obvallata against four bacterial strains have been represented in Table 2 .

\section{Antifungal activity}

The antifungal activity of extracts of leaves and flower of S. obvallata were assessed against three fungal species, Candida albicans (CA), Candida glabrata (CG) and Candida tropicalis (CT) in terms of zone of inhibition (ZOI). The zone of inhibition observed for the aqueous extract of leaves was $15.43 \pm 0.30 \mathrm{~mm}$ for $\mathrm{CA}, 8.30 \pm 0.15 \mathrm{~mm}$ for $\mathrm{CT}$, and $13.90 \pm 0.17 \mathrm{~mm}$ for CG. The ZOI for methanolic extract of leaves was $15.90 \pm 0.56 \mathrm{~mm}$ for $\mathrm{CA}, 13.17 \pm 0.09 \mathrm{~mm}$ for $\mathrm{CT}$, and $14.57 \pm 0.23 \mathrm{~mm}$ for CG. The ZOI for the aqueous extract of flowers was $14.30 \pm 0.12 \mathrm{~mm}$ for $\mathrm{CG}, 12.33$

Table 2 The antibacterial and antifungal activity of the extracts of leaves and flowers of Saussurea obvallata determined using the well diffusion method

\begin{tabular}{|c|c|c|c|c|c|c|c|}
\hline \multirow{2}{*}{$\begin{array}{l}\text { Plant } \\
\text { Extracts }\end{array}$} & \multicolumn{4}{|c|}{ Assay for antibacterial activity } & \multicolumn{3}{|c|}{ Assay for antifungal activity } \\
\hline & P. aeruginosa & E. coli & S. aureus & K. pneumoniae & C. glabrata & C. albicans & C. tropicalis \\
\hline L1 & $16.60 \pm 0.21^{c}$ & $11.57 \pm 0.23^{c}$ & $20.43 \pm 0.30^{b}$ & $14.90 \pm 0.21^{d}$ & $13.90 \pm 0.17^{b}$ & $15.43 \pm 0.30^{b c}$ & $8.30 \pm 0.15^{d}$ \\
\hline L2 & $13.90 \pm 0.21^{e}$ & $10.83 \pm 0.43^{c}$ & $13.60 \pm 0.21^{d}$ & $19.90 \pm 0.56^{b}$ & $14.57 \pm 0.23^{b}$ & $15.90 \pm 0.56^{b}$ & $13.17 \pm 0.09^{b}$ \\
\hline F1 & $20.50 \pm 0.26^{b}$ & $13.90 \pm 0.21^{b}$ & $16.53 \pm 0.24^{c}$ & $18.53 \pm 0.24^{c}$ & $14.30 \pm 0.12^{b}$ & $14.27 \pm 0.50^{c}$ & $12.33 \pm 0.18^{t}$ \\
\hline F2 & $16.33 \pm 0.17^{d}$ & $8.87 \pm 0.19^{d}$ & $12.83 \pm 0.17^{e}$ & $11.53 \pm 0.24^{e}$ & $14.30 \pm 0.47^{b}$ & $15.27 \pm 0.47^{\mathrm{bc}}$ & $10.90 \pm 0.46^{\circ}$ \\
\hline Drug & $34.33 \pm 0.33^{a}$ & $25.67 \pm 0.33^{a}$ & $31.33 \pm 0.33^{a}$ & $24.60 \pm 0.31^{a}$ & $22.40 \pm 0.31^{a}$ & $25.93 \pm 0.54^{a}$ & $25.97 \pm 0.49^{\circ}$ \\
\hline DMSO & $00.00 \pm 0.00$ & $00.00 \pm 0.00$ & $00.00 \pm 0.00$ & $00.00 \pm 0.00$ & $00.00 \pm 0.00$ & $00.00 \pm 0.00$ & $00.00 \pm 0.00$ \\
\hline
\end{tabular}

Mean values $\pm \mathrm{SE}$ followed by the same letter $(\mathrm{s})$ in a column are not significantly different $(p<0.05)$ based on DMRT; $P$. aeruginosa: Pseudomonas aeruginosa; $E$. coli: Escherichia coli; S. aureus: Staphylococcus aureus; K. pneumoniae: Klebsiella pneumoniae; C. albicans: Candida albicans; C. glabrata: Candida glabrata; C. tropicalis: Candida tropicalis. L1\& L2: aqueous and methanolic extract of leaves, respectively. F1 \& F2: aqueous and methanolic extract of flowers, respectively. Ampicillin and fluconazole were used as positive controls for antibacterial and antifungal assays, respectively. DMSO used as a negative control 
$\pm 0.18 \mathrm{~mm}$ for $\mathrm{CT}$, and $14.27 \pm 0.50 \mathrm{~mm}$ for CA. The ZOI for methanolic extract of flowers was $15.27 \pm$ $0.47 \mathrm{~mm}$ for CA, $10.90 \pm 0.46 \mathrm{~mm}$ for CT, and $14.30 \pm$ $0.47 \mathrm{~mm}$ for CG. Fluconazole (positive drug) showed maximum ZOI against CT $(25.97 \pm 0.49 \mathrm{~mm})$, followed by CA $(25.93 \pm 0.54 \mathrm{~mm})$, and CG $(22.40 \pm 0.31 \mathrm{~mm})$. DMSO does not show ZOI against any of the strains (CT, CA, CG). The results of antifungal activity of extracts of $S$. obvallata against three fungal strains have been represented in Table 2 .

\section{GC-MS analyses of methanolic extracts of Saussurea obvallata}

The results of GC-MS analyses of methanolic leaf and flower extracts of Saussurea obvallata showed the presence of 36 and 48 components, respectively based on separation of individual peaks through GC as per their retention time (Rt) and area per cent under individual peaks (Tables $3 \& 4$ ). The mass spectra of these compounds were matched with the spectra of known compounds listed in WILEY8.LIB and NIST08.LIB spectral databases/ libraries. Some of these components could not be identified by comparison using any of these libraries; such unidentified GC peaks numbered five (5; Rt: 9.113, 10.662, 10.887, 19.407, and $22.337 \mathrm{~min}$ ) in the flower extract and one (1; Rt: $15.552 \mathrm{~min})$ in the leaf extract. Most of the components presented in the extracts of leaves and flowers have been already reported in respect of different biological activities namely, Curumene (for anticancer), Methyl acetate (for hepatoprotective), Nerolidol acid (for antioxidant, anti-inflammatory and pesticide) and Piperine (malaria and respiratory disease), Stigmasterol (antioxidant, antimicrobial, anticancer) etc.

The major components in the methanolic extract of leaves of $S$. obvallata were Linoleic acid (22.50\%); followed by Dehydrocostus lactone (21.98\%); Palmitic acid (11.84\%); Eltanolone (11.43\%); and Doconexent (9\%). However, major components in methanolic flower extract of $S$. obvallata was not be identified by the known libraries (Rt: 19.40; 38.85\%,); followed by Methyle palmitate (12.18\%); Linalyl acetate (4.94\%); Palmitic acid (4.65\%); Methyl stearate (3067\%). After GC-MS analyses of both the extracts of $S$. obvallata, few components in leaves and flowers extract have already been reported for various biological activities, such as anti-oxidant, antimicrobial, hemolytic, cancer preventive, chemo preventive, anti-tumor, immuno-stimulant, etc. (Table 5). Furthermore, other uses of these components are in perfume industry, and in the preparation of pesticides, anti-androgenic formulations, flavour additives, and for sunscreens. Six (6) components, namely Palmitic acid, Methyl linoeate, Stearic acid, 1-Docosanol, Methyl oleate, Gama-Stearolactone, are common in both the
Table 3 Chemical composition of methanolic leaf extract of Saussurea obvallata

\begin{tabular}{|c|c|c|c|}
\hline SN & Name of components & Mol. Formula & Area per cent (\%) \\
\hline 1 & Octyl cyanide & $\mathrm{C}_{9} \mathrm{H}_{17} \mathrm{~N}$ & 0.17 \\
\hline 2 & Benzeneacetaldehyde & $\mathrm{C}_{8} \mathrm{H}_{8} \mathrm{O}$ & 0.10 \\
\hline 3 & Pyranone & $\mathrm{C}_{6} \mathrm{H}_{8} \mathrm{O}_{4}$ & 0.72 \\
\hline 4 & Pentadecane & $\mathrm{C}_{15} \mathrm{H}_{32}$ & 0.21 \\
\hline 5 & (RS)-nicotine & $\mathrm{C}_{10} \mathrm{H}_{14} \mathrm{~N}_{2}$ & 0.07 \\
\hline 6 & Tetradecane & $\mathrm{C}_{14} \mathrm{H}_{30}$ & 0.27 \\
\hline 7 & Amantadine & $\mathrm{C}_{10} \mathrm{H}_{17} \mathrm{~N}$ & 0.18 \\
\hline 8 & Hexadecane & $\mathrm{C}_{16} \mathrm{H}_{34}$ & 0.16 \\
\hline 9 & a-Bisabol oxide B & $\mathrm{C}_{15} \mathrm{H}_{26} \mathrm{O}_{2}$ & 0.15 \\
\hline 10 & Blumenol C & $\mathrm{C}_{13} \mathrm{H}_{22} \mathrm{O}_{2}$ & 0.08 \\
\hline 11 & Tetradecanoic acid & $\mathrm{C}_{14} \mathrm{H}_{28} \mathrm{O}_{2}$ & 0.10 \\
\hline 12 & N-Acetylimidazole & $\mathrm{C}_{5} \mathrm{H}_{6} \mathrm{~N}_{2} \mathrm{O}$ & 0.15 \\
\hline 13 & Androsterone, trifluoroacetate & $\mathrm{C}_{21} \mathrm{H}_{29} \mathrm{~F}_{3} \mathrm{O}_{3}$ & 0.08 \\
\hline 14 & Phytol & $\mathrm{C}_{20} \mathrm{H}_{40} \mathrm{O}$ & 0.25 \\
\hline 15 & Diisobutyl phthalate & $\mathrm{C}_{16} \mathrm{H}_{22} \mathrm{O}_{4}$ & 0.06 \\
\hline 16 & Eltanolone & $\mathrm{C}_{21} \mathrm{H}_{34} \mathrm{O}_{2}$ & 11.43 \\
\hline 17 & Proximadiol & $\mathrm{C}_{15} \mathrm{H}_{28} \mathrm{O}_{2}$ & 0.24 \\
\hline 18 & Doconexent & $\mathrm{C}_{22} \mathrm{H}_{32} \mathrm{O}_{2}$ & 9.00 \\
\hline 19 & Palmitic acid & $\mathrm{C}_{16} \mathrm{H}_{32} \mathrm{O}_{2}$ & 11.84 \\
\hline 20 & Dehydrocostus lactone & $\mathrm{C}_{15} \mathrm{H}_{18} \mathrm{O}_{2}$ & 21.98 \\
\hline 21 & Strophanthidin & $\mathrm{C}_{23} \mathrm{H}_{32} \mathrm{O}_{6}$ & 0.25 \\
\hline 22 & n-Nonadecanol-1 & $\mathrm{C}_{19} \mathrm{H}_{40} \mathrm{O}$ & 0.11 \\
\hline 23 & Methyl linoleate & $\mathrm{C}_{19} \mathrm{H}_{34} \mathrm{O}_{2}$ & 0.26 \\
\hline 24 & Linoleic acid & $\mathrm{C}_{18} \mathrm{H}_{32} \mathrm{O}_{2}$ & 22.50 \\
\hline 25 & Stearic acid & $\mathrm{C}_{18} \mathrm{H}_{36} \mathrm{O}_{2}$ & 2.38 \\
\hline 26 & 1-Docosanol & $\mathrm{C}_{22} \mathrm{H}_{46} \mathrm{O}$ & 1.75 \\
\hline 27 & Methyl oleate & $\mathrm{C}_{19} \mathrm{H}_{36} \mathrm{O}_{2}$ & 0.09 \\
\hline 28 & Bupleuronol & $\mathrm{C}_{17} \mathrm{H}_{20} \mathrm{O}_{2}$ & 1.23 \\
\hline 29 & Andrographolide & $\mathrm{C}_{20} \mathrm{H}_{30} \mathrm{O}_{5}$ & 0.31 \\
\hline 30 & Nitrocyclododecane & $\mathrm{C}_{12} \mathrm{H}_{23} \mathrm{NO}_{2}$ & 0.16 \\
\hline 31 & 1,2-Benzenedicarboxylic acid & $\mathrm{C}_{24} \mathrm{H}_{38} \mathrm{O}_{4}$ & 0.10 \\
\hline 32 & Stachydrine & $\mathrm{C}_{7} \mathrm{H}_{13} \mathrm{NO}_{2}$ & 0.37 \\
\hline 33 & Gama-Stearolactone & $\mathrm{C}_{18} \mathrm{H}_{34} \mathrm{O}_{2}$ & 0.91 \\
\hline 34 & Talaroconvolutin B & $\mathrm{C}_{32} \mathrm{H}_{43} \mathrm{NO}_{4}$ & 0.11 \\
\hline 35 & 22-Tricosenoic acid & $\mathrm{C}_{23} \mathrm{H}_{44} \mathrm{O}_{2}$ & 0.68 \\
\hline 36 & Litsomentol & $\mathrm{C}_{30} \mathrm{H}_{52} \mathrm{O}_{2}$ & 2.25 \\
\hline \multicolumn{3}{|c|}{ Total identified compounds } & $90.70 \%$ \\
\hline \multicolumn{3}{|c|}{ Unknown compounds } & $00.36 \%$ \\
\hline
\end{tabular}

extracts. While some components being common in both the extracts have not been reported to exhibit any biological activity.

To the best of our knowledge this would appear to be the first report regarding detailed phytochemical 
Table 4 Chemical composition of methanolic extract of flowers of Saussurea obvallata

\begin{tabular}{|c|c|c|c|}
\hline SN & Name of components & Mol. Formula & Area per cent \\
\hline 1 & a -Terpineol & $\mathrm{C}_{10} \mathrm{H}_{18} \mathrm{O}$ & 3.3 \\
\hline 2 & Methyl octanoate & $\mathrm{C}_{9} \mathrm{H}_{18} \mathrm{O}_{2}$ & 0.05 \\
\hline 3 & Cinnamaldehyde & $\mathrm{C}_{9} \mathrm{H}_{8} \mathrm{O}$ & 0.44 \\
\hline 4 & Linalyl acetate & $\mathrm{C}_{12} \mathrm{H}_{20} \mathrm{O}_{2}$ & 4.94 \\
\hline 5 & Eugenol & $\mathrm{C}_{10} \mathrm{H}_{12} \mathrm{O}_{2}$ & 0.66 \\
\hline 6 & Methyl eugenol ether & $\mathrm{C}_{11} \mathrm{H}_{14} \mathrm{O}_{2}$ & 0.21 \\
\hline 7 & Curumene & $\mathrm{C}_{15} \mathrm{H}_{24}$ & 2.79 \\
\hline 8 & Nerolidol & $\mathrm{C}_{15} \mathrm{H}_{26} \mathrm{O}$ & 0.28 \\
\hline 9 & n-Heptadecanol-1 & $\mathrm{C}_{17} \mathrm{H}_{36} \mathrm{O}$ & 0.08 \\
\hline 10 & Caryophyllene oxide & $\mathrm{C}_{15} \mathrm{H}_{24} \mathrm{O}$ & 0.56 \\
\hline 11 & Geranyl linalool isomer b & $\mathrm{C}_{20} \mathrm{H}_{34} \mathrm{O}$ & 0.16 \\
\hline 12 & n-Pentadecanol & $\mathrm{C}_{15} \mathrm{H}_{32} \mathrm{O}$ & 0.53 \\
\hline 13 & Heptadecane & $\mathrm{C}_{17} \mathrm{H}_{36}$ & 0.59 \\
\hline 14 & Pentadecyclic acid & $\mathrm{C}_{15} \mathrm{H}_{30} \mathrm{O}_{2}$ & 0.42 \\
\hline 15 & Methyl palmitoleate & $\mathrm{C}_{17} \mathrm{H}_{32} \mathrm{O}_{2}$ & 0.34 \\
\hline 16 & Methyl palmitate & $\mathrm{C}_{17} \mathrm{H}_{34} \mathrm{O}_{2}$ & 12.18 \\
\hline 17 & Bicyclohexyl & $\mathrm{C}_{12} \mathrm{H}_{22}$ & 0.12 \\
\hline 18 & Palmitic acid & $\mathrm{C}_{16} \mathrm{H}_{32} \mathrm{O}_{2}$ & 4.65 \\
\hline 19 & Stearic acid & $\mathrm{C}_{18} \mathrm{H}_{36} \mathrm{O}_{2}$ & 0.43 \\
\hline 20 & Lignoceric acid & $\mathrm{C}_{24} \mathrm{H}_{48} \mathrm{O}_{2}$ & 0.50 \\
\hline 21 & Methyl stearate & $\mathrm{C}_{19} \mathrm{H}_{38} \mathrm{O}_{2}$ & 3.67 \\
\hline 22 & Camphor & $\mathrm{C}_{10} \mathrm{H}_{16} \mathrm{O}$ & 0.96 \\
\hline 23 & Dibutyl sebacate & $\mathrm{C}_{18} \mathrm{H}_{34} \mathrm{O}_{4}$ & 1.04 \\
\hline 24 & Methyl linoleate & $\mathrm{C}_{19} \mathrm{H}_{34} \mathrm{O}_{2}$ & 0.31 \\
\hline 25 & Prodlure & $\mathrm{C}_{16} \mathrm{H}_{28} \mathrm{O}_{2}$ & 0.14 \\
\hline 26 & Menthyl acetate & $\mathrm{C}_{12} \mathrm{H}_{22} \mathrm{O}_{2}$ & 0.12 \\
\hline 27 & Rishitin & $\mathrm{C}_{14} \mathrm{H}_{22} \mathrm{O}_{2}$ & 0.07 \\
\hline 28 & 1-Docosanol & $\mathrm{C}_{22} \mathrm{H}_{46} \mathrm{O}$ & 0.21 \\
\hline 29 & Methyl linolenate & $\mathrm{C}_{19} \mathrm{H}_{32} \mathrm{O}_{2}$ & 0.14 \\
\hline 30 & Methyl oleate & $\mathrm{C}_{19} \mathrm{H}_{36} \mathrm{O}_{2}$ & 1.02 \\
\hline 31 & Henicosanoic acid & $\mathrm{C}_{21} \mathrm{H}_{42} \mathrm{O}_{2}$ & 2.24 \\
\hline 32 & Bornyl cinnamate & $\mathrm{C}_{19} \mathrm{H}_{24} \mathrm{O}_{2}$ & 0.19 \\
\hline 33 & Gama-Stearolactone & $\mathrm{C}_{18} \mathrm{H}_{34} \mathrm{O}_{2}$ & 0.12 \\
\hline 34 & Docosanoic acid & $\mathrm{C}_{22} \mathrm{H}_{44} \mathrm{O}_{2}$ & 0.18 \\
\hline 35 & Tridecanedial & $\mathrm{C}_{13} \mathrm{H}_{24} \mathrm{O}_{2}$ & 0.13 \\
\hline 36 & Gondoic acid & $\mathrm{C}_{20} \mathrm{H}_{38} \mathrm{O}_{2}$ & 2.92 \\
\hline 37 & Tricosanoic acid & $\mathrm{C}_{23} \mathrm{H}_{46} \mathrm{O}_{2}$ & 1.46 \\
\hline 38 & Deflazacortalcohol & $\mathrm{C}_{23} \mathrm{H}_{29} \mathrm{NO}_{5}$ & 0.10 \\
\hline 39 & Methyl nervonate & $\mathrm{C}_{25} \mathrm{H}_{48} \mathrm{O}_{2}$ & 0.15 \\
\hline 40 & Pentacosylic acid & $\mathrm{C}_{25} \mathrm{H}_{50} \mathrm{O}_{2}$ & 0.93 \\
\hline 41 & Squalene & $\mathrm{C}_{30} \mathrm{H}_{50}$ & 0.52 \\
\hline 42 & 17-Pentatriacontene & $\mathrm{C}_{35} \mathrm{H}_{70}$ & 0.06 \\
\hline 43 & Eicosane & $\mathrm{C}_{20} \mathrm{H}_{42}$ & 0.11 \\
\hline
\end{tabular}

Table 4 Chemical composition of methanolic extract of flowers of Saussurea obvallata (Continued)

\begin{tabular}{llll}
\hline SN & Name of components & Mol. Formula & Area per cent \\
\hline 44 & Piperine & $\mathrm{C}_{17} \mathrm{H}_{19} \mathrm{NO}_{3}$ & 0.18 \\
45 & Nonacosane & $\mathrm{C}_{29} \mathrm{H}_{60}$ & 0.10 \\
46 & Stigmasterol & $\mathrm{C}_{29} \mathrm{H}_{48} \mathrm{O}$ & 0.13 \\
47 & $\beta$ - Sitosterol & $\mathrm{C}_{29} \mathrm{H}_{50} \mathrm{O}$ & 0.17 \\
48 & Tetratetracontane & $\mathrm{C}_{44} \mathrm{H}_{90}$ & 0.10 \\
Total identified compounds & & $50.70 \%$ \\
Unknown compounds & & $39.53 \%$ \\
\hline
\end{tabular}

analysis, medicinal and anti-microbial properties, and discussion on the bioactive components of S. obvallata. During the present study, basic information has been generated about total phenolic \& flavonoid contents, antioxidant activity (using DPPH \& $\mathrm{H}_{2} \mathrm{O}_{2}$ assays), and antimicrobial activity. GC-MS analyses were carried out to elucidate the chemical composition of $S$. obvallata leaf and flower extracts (methanolic). The composition of plant extracts depend on their origin, extraction techniques used, the time and temperature of extraction, nature of solvent used, its concentration and polarity, quantity and the secondary metabolite composition of a given extract [63]. Variations in the extraction methods like the duration of the extraction period, the solvent used, $\mathrm{pH}$, temperature, particle size, and the solventto-sample ratio [64] can lead to different results. Phytochemical investigations of $S$. obvallata extracts showed that, as expected, it contains different types of constituents like alkaloids, flavonoids, terpenoids, glycosides, saponins, etc. using different solvents, e.g., methanol, ethanol, chloroform, and distilled water as solvents [11]. Similar pattern and constituents were reported by Alaagib \& Ayoub [65] for Saussurea lappa.

Phenolic and flavonoid compounds are produced by plants and are known to have strong anti-oxidant activity. They exert a positive effect on both plants and human health, and some derivatives of flavonoids possess antibacterial activity against a range of microbes. In the present study the maximum and minimum values for TPC were recorded for methanolic leaf extract and aqueous floral extract $(358.67 \pm 0.17$ and $132.67 \pm 0.17 \mathrm{mg}$ GAE $\mathrm{g}^{-1} \mathrm{dw}$, respectively) of $S$. obvallata, while maximum TFC $(326.88 \pm 2.11 \mathrm{mg}$ QE $\mathrm{g}^{-1} \mathrm{dw}$ ) was found in the aqueous floral extract, and the minimum TFC $\left(65.73 \pm 1.55 \mathrm{mg}\right.$ QE $\left.\mathrm{g}^{-1} \mathrm{dw}\right)$ was found in the methanolic extract of flowers. On the other hand, Saussurea involucrata was reported to possess significant anti-oxidant activity (high phenol and flavonoid content) and is known to be used by a large population in China for medicinal purpose [66]. Phenolic and flavonoid contents in Saussurea obvallata 
Table 5 Bioactive components present in the methanolic extracts of leaves and flowers of Saussurea obvallata

\begin{tabular}{|c|c|c|c|}
\hline SN & Components & Biological activity & References \\
\hline 1 & Benzeneacetaldehyde & Anti-microbial, anti-inflammatory. & [22] \\
\hline 2 & Pyranone & Anti-microbial, anti-inflammatory, anti-oxidant, anti-proliferative. & [23] \\
\hline 3 & Tetradecanoic acid & Anti-fungal, anti-oxidant, cancer-preventive, cosmetic. & [24] \\
\hline 4 & Phytol & Anti-microbial, anti-inflammatory, anti-nociceptive. & [25] \\
\hline 5 & Palmitic acid & Anti-androgenic, hemolytic, cancer preventive, sunscreen, perfumery. & [26] \\
\hline 6 & Methyl linoleate & Hepatoprotective, anti-microbial. & [27] \\
\hline 7 & Linoleic acid & Anti-inflammatory, anti-microbial. & {$[28,29]$} \\
\hline 8 & Gama-Stearolactone & Anti-tumor, anti-inflammatory, anti-convulsant activity. & {$[27,30-32]$} \\
\hline 9 & a -Terpineol & Contractile activity; anti-bacterial; anti-microbial; Insecticidal. & [32-36] \\
\hline 10 & Cinnamaldehyde & Anti-cancer, anti-microbial, anti-oxidant & [37] \\
\hline 11 & Curumene & Anti-tumor, anti-bacterial, anti-inflammatory, sedative, fungicide. & [38-43] \\
\hline 12 & Nerolidol & Anti-tumor, analgesic, anti-inflammatory, sedative, fungicide. & {$[44,45]$} \\
\hline 13 & n-Heptadecanol-1 & Anti-microbial, anti-inflammatory. & {$[46,47]$} \\
\hline 14 & Caryophyllene oxide & Anti-microbial, anti-inflammatory. & [48-52] \\
\hline 15 & Pentacosylic acid & Anti-bacterial. & {$[27,52,53]$} \\
\hline 16 & 1-Docosanol & Anti-microbial, anti-herpetic agent, wounds, anti-herpes. & [54-56] \\
\hline 17 & Methyl acetate & Anti-oxidant, anti-microbial, anti-inflammatory and phytotoxic. & [57] \\
\hline 18 & Piperine & Anti-oxidant, anti-microbial, anti-tumor, pesticide. & {$[58,59]$} \\
\hline 19 & $\beta$-Sitosterol & Anti-microbial, thyroid inhibitory, hypoglycemic effects. & {$[60,61]$} \\
\hline 20 & Stigmasterol & Anti-oxidant, thyroid inhibitory, hypoglycemic effects. & {$[60,61]$} \\
\hline 21 & Squalene & Anti-oxidant, anti-microbial, cancer preventive, pesticide. & [62] \\
\hline
\end{tabular}

are in general agreement with the previous findings on other species of Saussurea.

Free radicals can cause damage to essential proteins, DNA, lipids and also be attributed to various human diseases such as cancer, cardiovascular diseases, neurodegenerative disorders, etc. due to oxidative stress. The most important role of antioxidants is to suppress free radical mediated oxidation by inhibiting the production of free radicals through scavenging activity. Ascorbic acid was used as a standard antioxidant compound for DPPH assay, and $\mathrm{H}_{2} \mathrm{O}_{2}$ scavenging assay. Maximum per cent DPPH scavenging activity $(82.88 \pm 0.48 \%)$ was recorded in the methanolic extract of flowers, and the minimum $(29.25 \pm 0.86 \%)$ in the aqueous extract of flowers in S. obvallata. The maximum per cent $\mathrm{H}_{2} \mathrm{O}_{2}$ scavenging activity (41.05 \pm $0.46 \%$ ) was recorded in the methanolic leaf extract, and the minimum $(39.75 \pm 0.36 \%)$ in the aqueous leaf extract at $1 \mathrm{mg} \mathrm{mL}^{-1}$ concentration of extracts. The same pattern in respect of antioxidant activity by DPPH assay was observed by Yao et al. [67] from two polysaccharides (SCIP1-2 and CSIP2-3) isolated from Saussurea involucrata, and they reported $60.3 \%$ and $88.7 \%$ DPPH scavenging activity at a dose of $8 \mathrm{mg} \mathrm{mL}^{-1}$, respectively for the two polysaccharides. S. obvallata therefore contains more antioxidant potential compared to $S$. involucrata. In this test, it was observed that methanol as a solvent resulted in higher values for TPC, DPPH and $\mathrm{H}_{2} \mathrm{O}_{2}$ assays, while the aqueous extract resulted in higher values for TFC.

Nowadays, increased risk of infection and resistance against antibiotics has become a persistent and wide spread problem and antibiotics are often used indiscriminately against diseases causes by various microbes. Thus, it is an important task for investigators to be constantly in the lookout for an alternate chemical agent against theses human pathogens. In this study, four bacterial strains and three fungal strains were used for the analyses of antimicrobial activity of S. obvallata extracts. For aqueous leaf extract, the maximum ZOI $(20.43 \pm 0.30 \mathrm{~mm})$ was found in respect of $S$. aureus while the minimum ZOI $(11.57 \pm$ $0.23 \mathrm{~mm}$ ) was associated with $E$. coli. The maximum and minimum ZOIs in respect of methanolic leaf extract were $19.90 \pm 0.56 \mathrm{~mm}$ for $K$. pneumoniae and $10.83 \pm 0.43 \mathrm{~mm}$ for $E$. coli, respectively. The aqueous extract of flowers showed maximum ZOI (20.50 \pm $0.26 \mathrm{~mm}$ ) for $P$. aeruginosa and minimum ZOI (13.90 $\pm 0.21 \mathrm{~mm}$ ) for $E$. coli. The methanolic extract of flowers caused maximum ZOI $(16.33 \pm 0.17 \mathrm{~mm})$ for $P$. aeruginosa and minimum ZOI $(08.87 \pm 0.19 \mathrm{~mm})$ for E. coli. In general, it was observed using this test 
that $E$. coli exhibited resistance against both the extracts (lower ZOI).

In the case of antifungal activity of $S$. obvallata extracts, maximum ZOI $(15.43 \pm 0.30 \mathrm{~mm})$ was recorded in respect of $C$. albicans and the minimum ZOI $(08.30 \pm$ $0.15)$ was recorded for $C$. tropicalis. However, maximum ZOI $(15.90 \pm 0.56 \mathrm{~mm})$ in respect of $C$. albicans and the minimum ZOI $(13.17 \pm 0.09 \mathrm{~mm})$ in case of $C$. tropicalis were recorded in methanolic extract of leaves. Aqueous floral extract exhibited maximum ZOI $(14.30 \pm 0.12 \mathrm{~mm})$ for C. glabrata and minimum ZOI $(12.33 \pm 0.18 \mathrm{~mm})$ for C. tropicalis, while the maximum ZOI $(15.27 \pm 0.47 \mathrm{~mm})$ and minimum ZOI $(10.90 \pm 0.46 \mathrm{~mm})$ were found in respect of $C$. tropicalis. In this experiment, it has been shown that $C$. tropicalis exhibited resistance against $S$. obvallata extracts (lower ZOI). Khalid et al. [68] have reported antimicrobial activity of S. lappa root extract against three Gram positive and two Gram negative bacteria. Methanol, hot water and cold water were used for the extraction, and the range of zone of inhibition was observed between 10 and $18 \mathrm{~mm}$ for methanolic extract, $8-11 \mathrm{~mm}$ for hot water extract and $9-13 \mathrm{~mm}$ for cold water extract.

Antimicrobial activity of methanolic and chloroform extracts of S. lappa against E. coli, P. aeruginosa, $K$. pneumoniae, $P$. vulgaris, S. aureus, C. albicans, A. niger were reported by Thara \& Zuhra [69]. Both the extracts of $S$. lappa exhibited significant activity against all bacterial strains, but some fungal strains exhibited lower zone of inhibition. Antimicrobial activity of Saussurea lappa (roots) was reported by Negi et al. [70] the samples were collected from four different regions of Uttarakhand and methanol was used for the extraction. Negi et al. [70] tested six bacterial strains (S. typhimurium, E. coli, C. freundii, P. vulgaris, E. faecalis and S. aureus). The ZOIs were $6-8 \mathrm{~mm}$ for $E$. coli, $5-10 \mathrm{~mm}$ for $C$. freundii, 5-8 $\mathrm{mm}$ for E. faecalis and 6-10 $\mathrm{mm}$ for S. aureus. The extract of $S$. lappa exhibited excellent activity against these four bacterial strains compared to a known standard used. Two bacterial strains, Proteus vulgaris and S. typhimurium showed resistance against the root extract up to $100 \mathrm{mg} \mathrm{mL}^{-1}$ concentrations. Alaagib et al. [65] also reported antibacterial activity of S. lappa (black root) extract against five bacterial strains (B. subtilis, $S$. aureus, E. coli, P. aeruginosa and $K$. pneumoniae). Petroleum ether, chloroform, methanol, and water were used for extraction, and all five strains exhibited variable activity, Gram positive bacteria were more sensitive to the extract in comparison to Gram negative bacteria. The ZOIs caused by the root extract of S. lappa ranged from 11 to $21 \mathrm{~mm}$ (petroleum ether), 11-22 mm (chloroform), 11-17 mm (methanol), and 11-15 mm (water) extract. In respect of $E$. coli the zone of inhibition formed was quite low as also in the present study.
GC-MS analyses helped in the elucidation of chemical composition of both the extracts (leaves and flowers) of S. obvallata. Through these analyses thirty six (36) components were found to be present in the leaf extract, and forty eight (48) components in the flower extract. One (1) component in the leaf extract and five (5) components in the flower extract could not identified by known libraries. Total 21 components were enumerated as bioactive components in the two extracts based on previous studies, while 6 components were common in respect of both the extracts [71]. Many of the reported bioactive components were had been isolated from various sources, and already known for anti-oxidant and anti-microbial activity, etc. [72]. Thus, it can be concluded that the anti-oxidant and anti-microbial activities along with other medicinal properties associated with this plant may also be caused by theses bioactive components.

\section{Conclusions}

This study provides a fairly comprehensive report on TPC, TFC, anti-oxidant and anti-microbial activities, and GC-MS analyses of leaf and flower extracts of Saussurea obvallata. The results of present investigation are in general agreement with earlier studies on antioxidant, anti-microbial, and GC-MS analyses of other species of Saussurea genus. These results may provide a strong basis for traditionally known medicinal properties of $S$. obvallata, many of which are also mentioned in India holy books. Screening and identification of components and systematic evaluation of their medicinal properties may provide clues for a potential drug, and its other bioactivities may provide ground for these to be recommended for further investigations.

\section{Abbreviations}

DMSO: Dimethyl sulfoxide; DPPH: 2,2-diphenyl-1-picrylhydrazyl; GC-MS: Gas Chromatograpy - Mass Spectrometry; $\mathrm{H}_{2} \mathrm{O}_{2}$ : Hydrogen peroxide; TFC: Total flavonoids content; TPC: Total phenolic content

\section{Acknowledgements}

The authors wish to thank Prof. L.M.S. Palni, Prof. Ashish Thapliyal and Prof. Susheel Verma for providing facilities and encouragement. Help and support received from the Graphic Era (Deemed to be University), Dehradun, India and Jawahar Lal Nehru University, Delhi, India are gratefully acknowledged. We also thank Dr. Priyanka Sati for providing help during Statistical analysis.

\section{Funding}

Not applicable.

Availability of data and materials

All data generated or analysed during this study are included in this article.

\section{Authors' contributions}

PS collected the samples, performed all the experiments, and drafting the manuscript with SP. Both authors read the manuscript and approved the final version.

Ethics approval and consent to participate Not applicable. 


\section{Consent for publication}

Not applicable.

\section{Competing interests}

The authors declare that they have no competing interests.

\section{Publisher's Note}

Springer Nature remains neutral with regard to jurisdictional claims in published maps and institutional affiliations.

\section{Received: 26 June 2018 Accepted: 21 January 2019}

Published online: 01 March 2019

\section{References}

1. Vieira RF, Skorupa LA. Brazilian medicinal plants gene bank. Acta Hort. 1993; 330:51-8.

2. Singhal $S$, Agarwal A. Industrial utilization and promotion of medicinal plants in India. In: Chopra AK, Khanna DR, Prasad G, Malik DS, Bhutiani R editors. Medicinal Plant: Conservation Cultivation and Utilization. New Delhi: Daya Publishing House; 2007. p. 325-30.

3. Rawat VS, Chandhok A. Medicinal plants used by tribes of Uttarakashi District of Uttarakhand. Ind J Bot Res. 2009;5(3\&4):169-73.

4. Semwal P, Kapoor T, Anthwal P, Thapliyal A. Pittosporum eriocarpum royal (agni) endangered medicinal plant species of Uttarakhand and its conservation. Biotechnol Int. 2013;6(2):25-30.

5. Sharma AB. Global Medicinal Plants Demand May Touch \$5 Trillion By 2050. Indian Express 2004.

6. Pandey MM, Rastogi S, Rawat AKS. Saussurea costus: botanical, chemical and pharmacological review of an ayurvedic medicinal plant. J Ethnopharmacol. 2007;110:379-90.

7. Chick Wl, Zhu L, Yi T, Zhu GY, Gou XJ, et al. Saussurea involucrata: a review of the botany, phytochemistry and ethnopharmacology of a rare traditional herbal medicine. J Ethnopharmacol. 2015;172:44-60.

8. Fan JY, Chen HB, Zhu L, Chen HL, Zhao ZZ, Yi T. Saussurea medusa, source of the medicinal herb snow lotus: a review of its botany, phytochemistry, pharmacology and toxicology. Phytochem Rev. 2015;14:353-66.

9. Chen $\mathrm{QL}$, Chen XY, Zhu L, Chen HB, Ho HM, Yeung WP, et al. Review on Saussurea laniceps, a potent medicinal plant known as "snow lotus": botany, phytochemistry and bioactivities. Phytochem Rev. 2016;15:537-65 https:// doi.org/10.1007/s11101-015-9452-y.

10. Pant M, Semwal P. Brahma Kamal- the spiritually revered, scientifically ignored medicinal plant. Curr Sci. 2013;104(6):685-6.

11. Semwal $P$, Anthwal $P$, Kapoor T, Thapliyal A. Preliminary investigation of phytochemicals of Saussurea obvallata (Brahma Kamal) and Pittosporum eriocarpum (agni): endangered medicinal plant species of Uttarakhand. Int J Pharmacognosy. 2014;1 (4):266-9.

12. Mishra AP, Saklani S, Chandra S. Mineral elements, composition and antioxidant activity of Saussurea obvallata. The Herbs. 2013;1(1):5-9.

13. Sati SC, Joshi S. Antibacterial potential of leaf extracts of Juniperus communis L. from Kumaun Himalaya. Afr J Microbiol Res. 2010:4(12):1291-4.

14. Anand J, Upadhyaya B, Rawat P, Rai N. Biochemical characterization and pharmacognostic evaluation of purified catechins in green tea (Camellia sinensis) cultivars of India. 3 Biotech. 2015;5(3):285-94.

15. Azzahra LF, Fouzia H, Mohammed L, Noureddine B. Antioxidant response of Camellia sinensis and Rosmarinus officinalis aqueous extracts toward $\mathrm{H}_{2} \mathrm{O}_{2}$ stressed mice. J of Appl Phar Scie. 2012;02(07):70-6.

16. Panovska TK, Kulevanova S, Stefova M. In vitro antioxidant activity of some Teucrium species (Lamiaceae). Acta Pharma. 2005;55:207-14.

17. Anon. Pharmacopiea of India. 3rd edition. New Delhi, India: Ministry of Health and Family Welfare, Govt. of India; 1996.

18. Noumedem JAK, Tamokou JDD, Teke GN, Momo RCD. Phytochemical analysis, antimicrobial and radical scavenging properties of Acalypha manniana leaves. Springer Plus. 2013;2:503.

19. Ezhilan BP, Neelamegam R. GC-MS analysis of phytocomponents in the ethanol extract of Polygonum chinense L. Pharm Res. 2012;4(1):11-4

20. Das S, Vasudeva N, Sharma S. Chemical composition of ethanol extract of Macrotyloma uniflorum (lam.) Verdc. Using GC-MS spectroscopy. Organic and medicinal. Chem Lett. 2014:4:13.

21. Vinson JA, Dabbagh YA, Serry MM, Jang J. Plant flavonoids, especially tea flavonols, are powerful antioxidants using an in vitro oxidation model for heart disease. J Agri Food Chem. 1995;43(11):2800-2.
22. Cecotti R, Carpana E, Bergomi P, Tava A. Volatile constituents of Trifolium pratense spp. nivale quantified at different growth stages, and evaluation of their antimicrobial activity. Nat Prod Commun. 2013;8(11):1625-8.

23. Schaberle TF. Biosynthesis of a- Pyrones. Beilstein J Org Chem. 2016;12(12):571-88.

24. Agoramoorthy G, Chandrasekaran M, Venkatesalu V, Hsu MJ. Antibacterial and antifungal activities of fatty acid methyl esters of the blind - your - eye mangrove from India. Brazil J Microbiol. 2007;38:739-42.

25. Santos CCMP, Salvadori MS, Mota VG, Costa LM, Almeida AAC, Oliveira GAL, et al. Antinociceptive and antioxidant activities of phytol in-vivo and in-vitro models. Neuroscience J. 2013:2013;1-9 (article ID 949452). http://dx.doi.org/ 10.1155/2013/949452

26. Yin Y, Bi Y, Chen S, Yoncai L, Yi W, Yonghong G, et al. Chemical composition and antifungal activity of Cuticular wax isolated from Asian pear fruit (cv. Pingguoli). Sci Hort. 2011;129(4):577-82.

27. Rahman MM, Ahmad SH, Mohamed MTM, Rahman MZ. Antimicrobial compounds from leaf extracts of Jatropha curcas, Psidium guajava, and Andrographis paniculata. Scientific World J. 2014:2014;1-8 (Article ID 635240). http://dx.doi.org/10.1155/2014/635240.

28. Wei LS, Wee W, Siong JY, Syamsumir DF. Characterization of anticancer, antimicrobial, antioxidant properties and chemical compositions of Peperomia pellucida leaf extract. Acta Med Iran. 2011;49(10):670-4

29. Kalaivani CS, Sathish SS, Janakiraman N, Johnson M. GC-MS studies on Andrographis paniculata (Burm. f.) Wall. Ex Nees-a medicinally important plant. Int J Med Arom Plants. 2012;2(1):69-74.

30. Duke's phytochemical and ethnobotanical data base. (https://phytochem. nal.usda.gov/phytochem/search).

31. Krishnan K, Mani A, Jasmine S. Cytotoxic activity of bioactive compound 1, 2benzene dicarboxylic acid, mono 2- ethylhexyl ester extracted from a marine derived Streptomyces sp. VITSJK8. Int J Mol Cell Med. 2014;3(4):246-54.

32. Soares MCMS, Damiani CEN, Moreira CM, Stefanon I, Vassallo DV. Eucalyptol, an essential oil, reduces contractile activity in rat cardiac muscle. Braz J Med Biol Res. 2005;38(3):453-61.

33. Seol GH, Kim KY. Eucalyptol and its role in chronic diseases. Adv Exp Med Biol. 2016;929:389-98.

34. Zengin $\mathrm{H}$, Baysal AH. Antibacterial and antioxidant activity of essential oil terpenes against pathogenic and spoilage-forming bacteria and cell structure activity relationships evaluated by SEM microscopy. Molecules. 2014;19(11):17773-98.

35. Roy RN, Laskar S, Sen SK. Dibutyl phthalate, the bioactive compound produced by Streptomyces albidoflavus 321.2. Microbiol Res. 2006;161(2):121-6.

36. Khatiwora E, Adsul VB, Kulkarni M, Deshpande NR, Kashalkar RV. Antibacterial activity of Dibutyl phthalate : a secondary metabolite isolated from Ipomoed carnea stem. J Pharm Res. 2012:5(1):150-2.

37. Vishnuvardhanaraj G, Tamilvendan D, Amaladasan M. Synthesis, characterization and biological activities of cinnamaldehyde's mannich bases. Int Pharm Pharma Sci. 2013;5(3):821-5.

38. Legault J, Pichette A. Potentiating effect of beta-caryophyllene on anticancer activity of alpha-humulene, isocaryophyllene and paclitaxel. J Pharm Pharacol. 2007:59(12):1643-7.

39. Jun NJ, Mosaddik A, Moon JY, Jang KC, Lee DS, Ahn KS. Cytotoxic activity of beta-caryophyllene oxide isolated from Jeju guava (Psidium cattleianum Sabine) leaf. Rec Nat Prod. 2011;5(3):242-6.

40. Rogerio AP, Andrade EL, Leite DFP, Fiqueiredo CP, Calixto JB. Preventive and therapeutic anti-inflammatory properties of the sesquiterpene a-humulene in experimental airways allergic inflammation. Brit J Pharmacol. 2009;158(4):1074-87.

41. Nascimento AMA, Brandao MGL, Oliveira GB, Fortes IC. Synergistic bactericidal activity of Eremanthus erythropappus oil or $\beta$-bisabolene with ampicillin against Staphylococcus. Antonie Van Leeuwenhoek. 2007:92(1):95-100.

42. Mathew J, Thoppil JE. Chemical composition and mosquito larvicidal activities of Salvia essential oils. Pharm Biol. 2011:49(5):456-63.

43. Sharma P, Shah GC, Sharma R, Dhyani P. Chemical composition and antibacterial activity of essential oil of Nepeta graciliflora Benth. (Lamiaceae). Nat Prod Res. 2016;30(11):1332-4.

44. El-Tahir KEH, Abdel-Kader MS. Chemical and pharmacological study of Cymbopogon proximus volatile oil. Res J Med Plant. 2008;2(2):53-60.

45. Krist S, Banovac D, Tabanca N, Wedge DE, Gochev VK, Wanner J, et al. Antimicrobial activity of nerolidol and its derivatives against airborne microbes and further biological activities. Nat Prod Commun. 2015. 10(1):143-8. 
46. Rodilla JM, Tinoco MT, Morais JC, Gimenez C, Cabrera R, Martín-Benito $D$, et al. Laurus novocanariensis essential oil: seasonal variation and valorization. Biochem Syst Ecol. 2008;36(3):167-76.

47. Chavan MJ, Wakte PS, Shinde DB. Analgesic and anti-inflammatory activity of caryophyllene oxide from Annona squamosa L. bark. Phytomedicine. 2010;17(2):149-51.

48. Ghelardini C, Galeotti N, Mannelli LDC, Mazzanti G, Bartolini A. Local anaesthetic activity of $\beta$-caryophyllene. Farmaco. 2001;56(5-7):387-9.

49. Silva SL, Figueiredo PMS, Yano T. Chemotherapeutic potential of the volatile oils from Zanthoxylum rhoifolium lam leaves. Eur J Pharmacol. 2007;576(1-3):180-8.

50. Goren AC, Piozzi F, Akcicek E, Kilic T, Carıkci S, Mozioglu E. Essential oil composition of twenty-two Stachys species (mountain tea) and their biological activities. Phytochem Lett. 2011;4(4):448-53.

51. Ukil S, Laskar S, Roy RN. Physicochemical characterization and antibacterial activity of the leaf oil of Crotalaria pallida Aiton. J Taibah Univ Sci. 2016;10(4):490-6.

52. Kim DH, Park MH, Choi YJ, Chung KW, Park CH, Jang EJ, et al. Molecular study of dietary heptadecane for the anti-inflammatory modulation of NFkB in the aged kidney. PloS One. 2013;8(3):59316.

53. Elagbar ZA, Naik RR, Shakya RK, Bardaweel SK. Fatty acids analysis, antioxidant and biological activity of fixed oil of Annona muricata L. seeds. J Chem. 2016. https://doi.org/10.1155/2016/6948098.

54. Katz DH, Marcelletti JF, Khalil MH, Pope LE, Katz LR. Antiviral activity of 1docosanol, an inhibitor of lipid-enveloped viruses including Herpes simplex. Proc Natl Acad Sci U S A. 1991;88(23):10825-9.

55. Pope LE, Marcelletti JF, Katz LR, Lin JY, Katz DH, Parish ML, Spear PG. The anti-herpes simplex virus activity of $n$-docosanol includes inhibition of the viral entry process. Antivir Res. 1998;40(1-2):85-94.

56. Khalil MH, Marcelletti JF, Katz LR, Katz DH, Pope LE. Topical application of docosanol- or stearic acid-containing creams reduces severity of phenol burn wounds in mice. Contact Dermatitis. 2000;43(2):79-81.

57. Parker SR, Cutler HG, Jacyno JM, Hil RA. Biological activity of 6-Pentyl-2Hpyran-2-one and its analogs. J Agric Food Chem. 1997;45(7):2774-6.

58. Ahmad N, Fazal H, Abbasi BH, Faroog S, Ali M, Khan MA. Biological role of Piper nigrum L. (Black pepper): A review. Asian Pac J Trop Biomed. 2012:S1945-53.

59. Qu H, Lv M, Xu H. Piperine: bioactivities and structural modifications. Mini Rev Med Chem. 2015:15(2):145-56.

60. Panda S, Jafri M, Kar A, Meheta BK. Thyroid inhibitory, antiperoxidative and hypoglycemic effects of stigmasterol isolated from Butea monosperma. Fitoterapia. 2009;80(2):123-6.

61. Sayeed MSB, Karim SMR, Sharmin T, Morshed MM. Critical analysis on characterization, systemic effect, and therapeutic potential of beta-sitosterol: a plant-derived orphan phytosterol. Medicines. 2016; 3(4):2-25.

62. Huang ZR, Lin YK, Fang JY. Biological and pharmacological activities of squalene and related compounds: potential uses in cosmetic dermatology. Molecules. 2009;14(1):540-54.

63. Sofowora A. Medicinal plants and traditional medicine in Africa. Ibadan, Nigeria: Spectrum Books Limited; 1993.

64. Ncube NS, Afolayan AJ, Okoh Al. Assessment techniques of antimicrobial properties of natural compounds of plant origin: current methods and future trends. Afric J of Biote. 2008;7(12):1797-806.

65. Alaagib RMO, Ayoub SMH. On the chemical composition and antibacterial activity of Saussurea lappa (Asteraceae). Pharma Innov J. 2015;4(2):73-6.

66. Qiu J, Xue X, Chen F, Li C, Bolat N, et al. Quality evaluation of snow Lotus (Saussurea): quantitative chemical analysis and antioxidant activity assessment. Plant Cell Rep. 2010;29(12):1325-37.

67. Yao L, Zhao Q, Xiao J, Sun J, Yuan X, Zhao B, et al. Composition and antioxidant activity of the polysaccharides from cultivated Saussurea involucrata. Int J Biol Macromolec. 2012;50:849-53.

68. Khalid A, Rehman UU, Sethi A, Khilji S, Fatima U, et al. Saussurea lappa against gram positive and gram negative microorganisms. Afr J Biotechnol. 2011;10(22):4574-80.

69. Thara KM, Zuhra KF. Comprehensive In-vitro pharmacological activities of different extracts of Saussurea lappa. Eur J Exp Bio. 2012;2(2):417-20.

70. Negi JS, Bisht VK, Bhandari AK, Kuniyal CP, Bhatt VP, Bisht R. Chemical fingerprinting and antibacterial activity of Saussurea lappa Clarke. Appl Biochem Microbiol. 2014;50(6):588-93.
71. Semwal P. Investigations on reproductive biology, genetic variation and medicinal properties of Saussurea obvallata (DC.) Edgew. in Uttarakhand. Dehra Dūn: Ph.D. thesis. Graphic Era University; 2017.

72. Semwal P, Painuli S, Badoni H, Bacheti RK. Screening of phytoconstituents and antibacterial activity of leaves and bark of Quercus leucotrichophora A. Camus from Uttarakhand Himalaya. Clin Phytoscience. 2018;4(1):30 https://doi.org/10.1186/s40816-018-0090-y.

\section{Submit your manuscript to a SpringerOpen ${ }^{\circ}$ journal and benefit from:}

- Convenient online submission

- Rigorous peer review

- Open access: articles freely available online

High visibility within the field

- Retaining the copyright to your article

Submit your next manuscript at $>$ springeropen.com 